JETAL: JOURNAL OF ENGLISH TEACHING \& APPLIED LINGUISTICS

\begin{abstract}
VOLUME 2
Number 2

Page 56-61

e-issn:2714-9811

\section{The Effects of Wordle Media on Students' Vocabulary Mastery}

\author{
Nailul Author Restu Pamungkas \\ Yayasan Al Madina UNSIQ Wonosobo \\ nailulauthorrestup@gmail.com
}

ABSTRACT

The incorporation of technology-based media and teaching English vocabulary is considered to be puzzling. Teachers should take into account the students' learning style and their capabilities in operating the technology-based media. One of the practical technology-based media to teach vocabulary is Wordle. This study attempted to examine the effectiveness of an intervention using Wordle media to improve students' vocabulary mastery. This study involved 74 students of a private vocational school in Bandung. A quasi experimental research study was employed as the design of research. The findings indicated that implementing Wordle media proves to be effective in enhancing the students' vocabulary mastery. There is significance differences between experimental and control classes.
\end{abstract}

Keywords: Wordle media, vocabulary mastery, effects.

\section{Introduction}

Learning English as foreign language is considered to be puzzling, as it requires a lot of words of the target language to be mastered. Hence, mastering vocabulary takes a very great attention for foreign language learners. Rabu and Talib state that English vocabulary plays an important role in acquiring foreign language (2017). Generally speaking, foreign language learners acclaim that second language acquisition is dealing with vocabulary (Alqahtani, 2015). Thus, they devote their learning phase to memorize numerous target words as the main resources to communicate. Hence, it is true that words are considered as basic means of communication. As a matter of fact, learners who have lack of vocabulary problem will face low achievement in school. According to Bauman, Kame'enui and Ash (2013), the fundamental purpose of teaching English vocabulary is to assist students to discover the entailing of divers words. Subsequently, they are able to communicate efficiently and write in English with creativity as well as confidence. Moreover, to gain the information in a text, students are required to understand the words that signify the concepts of ideas. Considering the vital role of vocabulary in acquiring second and/or foreign languages, many researchers have been conducted studies to find out the most effective strategy or media to teach vocabulary ( $\mathrm{Li} \&$ Cummins, 2019; Rabu\&Talib, 2017; Arndt \&Woore, 2018; Ramezanali, \&Faez, 2019; Chiang, 2019; AlJohali, 2019).

The majority of prior studies explored technology based media to develop students' vocabulary ability. It is because the advance of developing technology will generate positive learning environment. It is, indeed, that technology or digital-based approach is able to build students' vocabulary mastery through interesting activities and attractive layouts. Moreover, technology is now being judged as a part of human life (Tuttle, 2005). Additionally, to prepare the competent human resources, educational system should fulfil the 21 st century digital era demands. In this case, teachers are no longer being a central of learning. Instead, they 
should act as facilitators because nowadays knowledge and information can be easily accessed by the students through information and communication technology (ICT). According to Hussain (2018), the 21st-century information and communication technology carried many advantages of various aspects of living particularly in educational field. With the advance development of ICT, teachers and practitioners are needed to take advantages and bring it to their classrooms. Thus, the students can get better learning experience and they will get better outcome as well. ICT deals with communication tools or devices in the form of software, hardware, telephones, network, radio, computer and television (Khan et al., 2015). Therefore, ICT can be used to teach English vocabulary in order to offer better outcome of students' vocabulary mastery.

Latest research studies have been conducted to examine the benefit of ICT implementing in the language classroom, and they found that it is proved to be effective for written and verbal communication (Pazio, 2010; Schmidt \&Hegelheimer, 2014; Khazaei\&Dastjerdi, 2011). That is why a lot of educational institutions in various levels bring technology-based media and traditional face to face teachings into their classrooms to develop students' vocabulary mastery. Teaching English vocabulary by carrying web-based or digital media is not thoroughly a novel trend (Tosun, 2015). It has been understood that bringing technology-based media is able to accommodate students to be autonomous learners. Learning by using technology-based media can also facilitate the students' learning style. Moreover, focusing the divers individual students' character, Lightbown and Spada (2013) judge that instructor is able to aid students enlarge their collections of learning strategy.

However, teaching English vocabulary by using technology is not an easy task to do. Berne and Blachowicz (2008) reveal that a lot of teachers feel unconfident to select the appropriate technology-based media to assist them in teaching vocabulary. It is because some teachers are still illiterate in digital technology. They are not accustomed to use technology in their daily life. In fact, the majority of teachers in Indonesia come from three generations, they are: baby boomers or $\mathrm{X}$ generations, millennial generations or $\mathrm{Y}$ generation and alpha generations or $\mathrm{Z}$ generations. Hence, some group of teachers are not capable to implement technology-based media in their classrooms. Moreover, the incorporation of technologybased media and curriculum in Indonesia is still struggling to be implemented smoothly.

Though, technology-based media can provide benefits in teaching and learning process. Thus, teachers' digital competence and learners' preference are needed to be taken into consideration in order to optimize the outcome. The first step of optimizing the outcome is to select the appropriate media by considering the teachers' competence and learners' preference. One of the practical web-based media is Wordle, as it is very easy to operate. Teachers with little or no experience in digital technology are able to implement it on their classrooms. Wordle is a web 2.0 tool. It is a word graphic art that combines any piece of text to create a visual depiction of the subject matter and coin words clouds from text. The more frequent certain words appear, the larger their size will be. Vice versa, the less frequent the words appear, the smaller their size will be. This medium also allows the users to change the colors, layout, even style of the words that can grab students' attention. That is why, this media is said to be able to inflame learners' ideas of the meaning, significance and correlation of words through creating, analyzing and communicating activities. Wordle is used to emphasize keywords and topics to be discussed before or after reading activities. This study attempted to examine the effectiveness of Wordle media in improving the students' vocabulary achievement.

\section{Method}

This study is considered as a Quasiexperimental design which used quantitative approach. The data were gained by distributing the pre-test and post-test in order to get the students' scores before and after the treatment. The pre-test is conducted at the beginning of the lesson in order to find out the initial differences between the control and experimental groups. The post test is conducted in order to check the difference between two groups after receiving treatment. The experimental class was taught by 
using Wordle method, while the control class was taught by using conventional method without using any digital media. After the scores are calculated, the researcher analyzed the result from the two groups statistically. The effect of the intervention is analyzed by employing t-test. If there is significance differences between experimental group and control group, it means that the treatment has significance influence. To analyze the gained data, four steps were employed, namely normality data, homogeneity of variance test, testing hypothesis by using ttest and determining the total gain. Whereas, the population of this study was the eleventh grade students of a private vocational school in Bandung which consists of 230 students. On the other hand, the sample was carried out from two classes-experimental and control classes- which have 37 students on each class.

\section{Findings}

The presentation of data analysis was intended to find out the result calculation of the gained data. It aims to answer the statement of research question dealing with how significant is the differences of the students' vocabulary ability between students who used Wordle media and without using it. Then, the result will be calculated by using statistical calculation. The first step is calculating normal distribution of pre-test data both experimental and control classes. The result is presented in the following table 1 .

Table 1.

Test of Normality (Pre-Test)

\begin{tabular}{lcc}
\hline Group & $\begin{array}{l}\text { Determining } \\
\text { the Degree of } \\
\text { Freedom }\end{array}$ & $\begin{array}{l}\text { Determining } \\
\text { the } \boldsymbol{X}_{\text {table }}^{\mathbf{2}} \\
\text { *chi square } \\
\text { table) with } \\
\text { significance } \\
\text { level 5\% }\end{array}$ \\
\hline Experimental group & $d f=3$ & 7,81 \\
Control group & $d f=3$ & 7,81
\end{tabular}

Moreover, the data is interpreted as normal distribution if $X_{\text {count }}^{2}<X_{\text {table }}^{2}$. Table 1 reveals that $X_{\text {count }}^{2}=3,51$ is less than $X_{\text {table }}^{2}=$ 7,81 . Therefore, the result data of pre-test in experimental class was interpreted as the normal distribution. Whereas, according to the findings from control group, it is concluded that $X_{\text {count }}^{2}$ $=2,94$ was less than $X_{\text {table }}^{2}=7,81$. Besides, the result data of pre-test in control class was determined as the normal distribution as well. In addition, the normality data distribution on posttest both in experimental and control groups has similar result to pre-test data. After testing the normal distribution data, the present study tested the homogeneity of variance.

Testing homogeneity of pre-test endeavours to gain the homogeneity data between pre-test data in experimental class and control classes. The statistical calculation as on the following table:

Table 2.

Homogeneity of Pre-Test Data

\begin{tabular}{lc}
\hline \multicolumn{1}{c}{ Homogeneity of Pre-Test Data } & $\begin{array}{l}\text { Result } \\
\text { Score }\end{array}$ \\
\hline Determining chi square count $\left(X_{\text {count }}^{2}\right)$ & 0,73 \\
$\begin{array}{l}\text { Determining the Degree of Freedom }(d f) \\
\begin{array}{l}\text { Determining chi square table }\left(X_{\text {table }}^{2}\right) \text { with } \\
\text { significance level 5\% }\end{array}\end{array}$ & 36 \\
\end{tabular}

According to the table 2 , the data was interpreted as the homogeneous data if $X_{\text {count }}^{2} \leq$ $X_{\text {table }}^{2}$. From the gained data $X_{\text {count }}^{2}=0,73$ while $X_{\text {table }}^{2}=1,78$. In conclusion, the score of chi square count $\left(X_{\text {count }}^{2}\right)$ was less than chi square table $\left(X_{\text {table }}^{2}\right)$ and the pre-test data of experimental class and control class were clarified as homogeneous data. Furthermore, the result of the homogeneity of the post-test data is presented in the below table.

Table 3.

Homogeneity of Post-test Data

\begin{tabular}{lc}
\hline \multicolumn{1}{c}{ Homogeneity of Pre-Test Data } & $\begin{array}{l}\text { Result } \\
\text { Score }\end{array}$ \\
\hline Determining chi square count $\left(X_{\text {count }}^{2}\right)$ & 0,93 \\
$\begin{array}{l}\text { Determining the Degree of Freedom }(d f) \\
\begin{array}{l}\text { Determining chi square table }\left(X_{\text {table }}^{2}\right) \text { with } \\
\text { significance level 1\% }\end{array}\end{array}$ & 36 \\
\hline
\end{tabular}

Based on the statistical data on the table above, the data was identified as the homogeneous data if $X_{\text {count }}^{2} \leq X_{\text {table }}^{2}$. From the gained data, it is revealed that $X_{\text {count }}^{2}$ was 0,93 while $X_{\text {table }}^{2}$ was 1,78 . In conclusion, the score of chi square count $\left(X_{\text {count }}^{2}\right)$ was less than chi square table $\left(X_{\text {table }}^{2}\right.$ ) and the post-test data of experimental class and control class were identified as homogeneous data. In the end, after concluding the output data 
shared homogeneity, it is necessary to test the hypothesis.

The testing hypothesis is conducted to figure out the result of the research whether the treatment has a significant different or not in improving students' vocabulary ability. It is used t-test to examine the hypothesis. The pre-test data was used to know whether the result between two classes was balance so that it is appropriate to receive the treatment. The gained data of the statistical calculation as follows:

Table 5.

Pre-test Testing Hypothesis

\section{Calculating Data Result Score}

\begin{tabular}{|c|c|}
\hline $\begin{array}{l}\text { Determining the } \\
\text { standard deviation ( } \\
s \text { ) }\end{array}$ & $\begin{array}{c}s_{1}=40,40 \\
s_{2}=35,82\end{array}$ \\
\hline Determining $t_{\text {count }}$ & $t_{\text {count }}=1,59$ \\
\hline $\begin{array}{l}\text { Determining } \\
t_{\text {table }} \text { with } \\
\text { significance level } \\
5 \%\end{array}$ & $t_{\text {table }}=1,67$ \\
\hline
\end{tabular}

Based on the result data of statistical calculation on the table above, the gained data indicates that $t_{\text {count }}$ is 1,59 while $t_{\text {table }}$ is 1,67 . It means that $t_{\text {count }}$ is lower than $t_{\text {table }}$. Then, based on the statistical value if $t_{\text {count }}>t_{\text {table }}$, it means both of two classes are balance and they are appropriate to receive treatment. After students receiving treatments, the post-tests were distributed for both experimental and control classes. Here is the result of the post-test testing hypothesis:

Table 6.

Post-test Testing Hypothesis

\begin{tabular}{lc}
\hline \multicolumn{1}{c}{ Calculating Data } & Result Score \\
\hline Determining the standard deviation $(s)$ & $s_{1}=66,35$ \\
& $s_{2}=60,97$ \\
Determining $t_{\text {count }}$ & $t_{\text {count }}=2,16$ \\
$\begin{array}{l}\text { Determining } t_{\text {table }} \text { with significance level } \\
5 \%\end{array}$ & $t_{\text {table }}=1,67$ \\
\hline
\end{tabular}

Based on the result data of statistical calculation on the table above, the gained data indicates that $t_{\text {count }}$ is 2,16 while $t_{\text {table }}$ is 1,67 . It means that $t_{\text {count }}$ is higher than $t_{\text {table. }}$ Then, based on the statistical value if $t_{\text {table }} \leq t_{\text {count }} \leq+t_{\text {table }}$, $\mathrm{Ha}$ is accepted and Ho is rejected. Ha: there is significant difference between students' vocabulary ability that using Wordle media and without using Wordle media. Ho: there is no significant difference between students' vocabulary ability that using Wordle media and without using it. Finally, the calculating of the total gain will provide the significant different data of experimental class and control class. In other words, the total gain was the degree of Wordle media influence, as on the following table:

\section{Table 7}

Determining the Total Gain

\begin{tabular}{lc}
\hline \multicolumn{1}{c}{ Calculating Data } & $\begin{array}{l}\text { Result } \\
\text { Score }\end{array}$ \\
\hline Experimental Class (using wordle media) & 0,43 \\
$\begin{array}{l}\text { Control Class (without using wordle } \\
\text { media) }\end{array}$ & 0,37 \\
\hline
\end{tabular}

The table 7 reveals that the total gain score of experimental class is 0,43 (medium), it is better than the total gain score of control class that is 0,37 (low). The difference between both classes is considered to be significant.

\section{Discussion}

By considering the findings, it can be clearly identified that null hypothesis $\mathrm{HO}$ is rejected as a result of significance difference which demonstrates that pupils who received Wordle media showed better English vocabulary achievement comparing to pupils who experienced conventional method-without using Wordle or any kind of digital media. In addition, this finding also discloses that the students from experimental group got higher mean score of post-test than that of the pre-test. The experimental group obtained the treatment in learning vocabulary by using Wordle media provides positive output to the students. It is because in learning vocabulary through Wordle, students can be stimulated by the creatively designed words. Consequently, it serves students to correlate the words in meaning-making. They can explore the meaning of the given words and look for the relationship among them. Wordle facilitates us to create a word based on the 
incidence of words in certain text. Students can integrate the bigger words into the text so they can get the meaning through the context. This condition is similar to Marzano'svocabulary learning strategy that the learners have to portray, accommodate an explanation, provide non-linguistic meaning, and discus in learning words (Scurletis, 2009). Some prior studies have conducted research dealing with the effects of digital media/ICT based media on students' vocabulary mastery.

Learning vocabulary by using ICT based media offers statistically significance difference (Eren, 2015; Sadikin, 2015; Khany\&Khosravian, 2014). Even though, they implemented differences types of ICT in general, the students performed better in vocabulary achievement. Additionally, facilitating digital media on learning English proposes another positive output that is students can engage and motivate in learning process. It has been proved by Young and Wang (2014), they explored the integrating game strategies to facilitate students in improving their pronunciation. It is proved that low-achievement students were active and involved in practicing speaking via the game. Another finding, Letchumanan et al. (2015) claim that digital media can significantly increase the attainment of students' English skills. Therefore, teaching English using Wordle enables the students to improve their vocabulary ability. Furthermore, the integrating of the digital features and vocabulary learning content will influence the students to involve in learning and reach the learning objective (Garries, 2002). The explanation on this finding study could be illustrated that Wodle has interesting presentation to trigger students to be active learning and engage in learning process (Tafazoli, 2013). Consequently, the students can increase their vocabulary mastery. As has been mentioned before, this present study indicates that teaching English vocabulary by implementing Wordle during learning process offers significance influence to students' vocabulary mastery. The findings of this study are parallel with Rabuand Talib (2017) who confirmed that learners who were provided digital game based learning demonstrated better English vocabulary attainment. Additionally, they also explored the students' acceptance level toward digital game based learning, and they acclaimed good acceptance on it.

\section{Conclusion}

Based on the statistical findings, implementing Wordle media to eleventh grade students of vocational school could increase their vocabulary achievement. Furthermore, there is differences the mean scores between control and experimental classes. It also revealed that the score difference between the control and experimental groups was considered to be significantly different. It is suggested that implementing Wordle proved to be effective in increasing students' vocabulary mastery. Thus, it is highly recommended to use Wordle in teaching English vocabulary. Moreover, teachers are also required to be creative and innovative in developing sort of media in teaching learning process in order to create conducive atmosphere. It is essential for the teachers to take their students' learning style into account by facilitating the right technology-based media so that their students can get better learning outcomes.

\section{References}

Al-Johali, K., Y., E. (2019). Teaching Vocabulary through Wiki to First Secondary Graders. English Language Teaching; 12 (5). 42-54.

Alqahtani, M. (2015). The Importance of Vocabulary in Language Learning and How to Be Taught. International Journal of Teaching and Education, 3(3), 21-34.

Arndt, H. L., \&Woore. R. (2018).Vocabulary learning from watching YouTube videos and reading blog posts. Language Learning \&Technology, 22(1), 124-142. Retrieved from https://doi.org/10125/44660

Baumann, J. F., Kame'enui, E. J., \& Ash, G. E. (2003). Research on Vocabulary Instruction: Voltaire Redux. Handbook of research on teaching the English language arts, 2, 752-785.

Berne, J.I., \&Blachowicz, C.L.Z. (2008). What Reading Teachers Say about Vocabulary Instruction: Voice from the Classroom. The Reading Teacher, 62(4), 314-323.

Chiang, H., H. (2019). A Comparison between Teacher-Led and Online Text-to-Speech Dictation for Students' Vocabulary Performance. English Language Teaching; 12 (3). 77-93.

Eren. M. (2015). Vocabulary learning on learnercreated content by using web 2.0 tools. 
Contemporary Educational Technology, 5(4), 281-300.

Garris, R., Ahlers, R., \&Driskell, J. E. (2002). Games, Motivation, and Learning: A Research and Practice Model. Simulation \& Gaming, 33(4), 441-467. Retrieved from https://doi.org/10.1177/1046878102238607

Hussain, Z. (2018). The effects of ICT-based learning on students' vocabulary mastery in junior high schools in Bandung. International Journal of Education, 10(2), 149-156. doi: http://dx.doi.org/10.17509/ije.v10i2.7592

Khan, M.S., Khan, I., U-Din, S., \& Jan, R. (2015). The impacts of ICT on the students' Performance: A Review of Access to Information. Research on Humanities and Social Sciences, 5(1), 85-94.

Khany, R. \&Khosravian, F. (2014). Iranian EFL learners' vocabulary development through Wikipedia. English Language teaching, 7(7). 57-67.

Khazaei, S., Dastjerdi, H.V. (2011). An Investigation into the Impact of Traditional vs. Blended Teaching on EFL Learners' Vocabulary Acquisition: M-learning in Focus. International Journal of Humanities and Social Science, 1(15), 202-207

Letchumanan, K., Tan, B. H., Paramasivam, S., Sabariah, M. R., \&Muthusamy, P. (2015). Incidental Learning of Vocabulary through Computer-Based and Paper-Based Games by Secondary School ESL Learners. Pertanika Journal of Social Sciences \& Humanities, 23(3), 725-740.

Li, J., \& Cummins, J. (2019). Effect of using texting on vocabulary instruction for English learners. Language Learning \& Technology, 23(2), 4364. Retrieved from https://doi.org/10125/44682

Pazio, M. (2010). Blended learning and its potential in expanding vocabulary knowledge: A case study. Teaching English with Technology, 10(1) 3-30.

Rabu, S. N. A., \&Talib, Z. (2017). The Effects of Digital Game-based Learning on Primary School Students' English Vocabulary Achievement and Acceptance. Innovative Teaching and Learning Journal, 1 (1), 61-74.

Ramezanali, N., \&Faez, F. (2019). Vocabulary learning and retention through multimedia glossing. Language Learning \& Technology, 23(2), 105-124. Retrieved from https://doi.org/10125/44685

Sadikin. I.S. (2016). The use of web quest for teaching English vocabulary in an EFL young learner context. ICTTE, 1(1), 403-410.

Schmidt, E. \&Hegelheimer, V. (2004). Effects of Online Academic Lectures on ESL Listening Comprehension, Incidental Vocabulary Acquisition, and Strategy Use. Computer Assisted Language Learning 17(5), 525-564.

Scurletis, G. (2009). Marzano's six steps to effective Vocabulary instruction, VISUAL THESAURUS; workshop vocab activities for your classroom. Retrieved from https://www.visualthesaurus.com/cm/wordsho p/marzanos-six-steps-to-effective-vocabularyinstruction/

Tafazoli, D. (2013). Wordling: Using Word Clouds in Teaching English Language. The Journal of Instructional Technology and Distance Learning, 10(8), 53-58.

Tuttle, H.N. (2005). Human life is radical reality: An idea developed from the conceptions of Dilthey, Heidegger, and Ortega y Gasset. Peter Lang Publishing: New York.

Young, S. S. C., \& Wang, Y. H. (2014). The game embedded CALL system to facilitate English vocabulary acquisition and pronunciation. Educational Technology and Society, 17(3), 239-251. 